\author{
M.M. Berest ${ }^{1}$, O.P. Koiuda ${ }^{2}$ \\ ${ }^{I}$ Simon Kuznets Kharkiv National University of Economics, Ukraine \\ ${ }^{2}$ O.M. Beketov National University of Urban Economy in Kharkiv, Ukraine
}

\title{
ANALYSIS AND DIAGNOSTICS OF CRISIS PHENOMENA IN THE ACTIVITIES OF UKRAINIAN ENTERPRISES
}

\begin{abstract}
Key analytical directions are proposed and the economic content of financial indicators for diagnosing crisis phenomena in the activities of business entities is disclosed. Based on the developed set of indicators, an analysis of the development of crisis phenomena in the activities of enterprises in Kharkiv region for the period 2016-2020 was carried out. The problematic spheres of activity of enterprises, in which manifestations of the crisis are observed, have been identified.
\end{abstract}

Keywords: analysis, diagnostics of crisis phenomena, financial indicators, profitability, financial stability.

\section{Formulation of the problem}

The emergence and development of crisis phenomena in the activities of enterprises is an objective process inherent in almost all economic entities at different stages of their functioning, regardless of the industry, size, organizational and legal form and other characteristics. In turn, this leads to negative consequences both for the enterprises themselves (a decrease in the efficiency of activities, a deterioration in the financial condition) and for the country's economy as a whole (an increase in the number of unprofitable enterprises and bankrupt enterprises, a decrease in budget revenues, delays in payment of wages, etc. social payments, etc.). Thus, according to the State Statistics Service of Ukraine, the share of unprofitable enterprises in 2020 amounted to more than $28 \%$, and the volume of losses received by them more than doubled compared to 2019, and reached UAH 542406.3 million [1].

In this regard, one of the most important tasks of enterprise management is the timely and complete diagnosis of the manifestations of the crisis in various areas and areas of its activities. This makes it possible to quickly, adequately and effectively respond to the crisis situation of the enterprise management bodies in order to minimize the negative consequences of the crisis and restore stable functioning.

\section{Analysis of previous research and publications}

The problems of analytical research and diagnostics of crisis phenomena in the activities of business entities were considered in the works of both Ukrainian and foreign scientists. Among the developments of domestic authors, one can single out the discriminant models of O.A. Tereshchenko [2], the model for assessing the likelihood of bankruptcy
A.V. Matveychuk [3], models for calculating the integral indicator of financial condition for assessing the probability of a debtor's default, recommended by the NBU [4], the Ministry of Finance of Ukraine [5], etc. Blank I.A. [6] considered approaches to conducting express diagnostics and fundamental diagnostics of crisis symptoms of financial development of an enterprise, while highlighting the objects of observation of the "crisis field" of an enterprise.

Among the developments of foreign scientists, methods for assessing the likelihood of bankruptcy of enterprises are most often used, in particular, the models of E. Altman (USA), J. Fulmer (France), R. Lys (Great Britain), J. Conan and M. Golder (France), R. Tuffler and G. Tishaw (Great Britain), J. Lego (Canada), G. Springate (Canada), W. Beaver (USA), D. Duran (France) and others.

At the same time, further research requires approaches to the selection and use of a set of financial indicators, which are used to assess and diagnose the presence and depth of manifestation of crisis phenomena in the activities of Ukrainian enterprises.

\section{Forming the purpose of the article}

The aim of the study is a comprehensive analysis and diagnostics of the development of crisis phenomena on the example of Ukrainian enterprises in various industries and the identification of key problem areas in their activities.

\section{Presentation of the main material}

An earlier analysis of literature sources and guidelines for assessing crisis phenomena in [7] showed that the diagnosis of the crisis state of enterprises is complex and involves the use of financial ratios in different analytical areas. In this regard, based on the results of a comparative analysis of the coefficient 
composition of domestic and Ukrainian methods, for a comprehensive assessment of the development of crisis phenomena in the activities of enterprises, it is proposed to use the following set of financial indicators in the context of key areas of diagnostics:

1) to assess the capital structure (financial stability) - the coefficient of financial independence (autonomy) as an indicator of the company's ability to cover part of its assets with its own funds. It is calculated as the ratio of equity to the total capital of the enterprise, the recommended value is $\geq 0.5$. The indicator in its most general form determines the actual level of financial autonomy and independence of the enterprise from external sources of financing;

2) to assess the structure of assets - the ratio of the net working capital and the total value of the assets of the enterprise. This indicator has a high frequency of use in the models of foreign authors and allows you to assess the degree of financial independence of an enterprise from external sources of financing. Net working capital is calculated as the difference between current assets and current liabilities and shows how much current assets are financed from long-term sources of financing (own and long-term borrowed funds). Accordingly, a drop in the share of net working capital in assets will indicate a decrease in the level of financial stability. Deterioration of the financial condition of the enterprise and the growth of its dependence on short-term borrowed capital;

3) for assessing profitability - the return on assets ratio, which is calculated as the ratio of net profit (or profit before interest and taxes) to the total value of the assets of the enterprise. This indicator reflects the overall level of efficiency of the company and the use of its assets. The growth in the level of return on assets indicates not only an increase in profitability, but also of the company's ability to increase the degree of financial stability and security due to a potential increase in the share of profit in the structure of funding sources.

In addition, in our opinion, it is advisable to additionally use the operating profitability ratio, which will expand the analyst's capabilities in identifying weaknesses and more clearly identify the manifestations of the crisis in the company's activities. This indicator is calculated as the ratio of financial results from operating activities and costs directly involved in the manufacture and sale of products (performance of work, provision of services). The negative dynamics of these ratios is a sign of low financial performance and can lead to a deepening crisis in the activities of an economic entity;

4) to assess the rate of turnover of enterprise resources - the asset turnover ratio. This indicator is calculated as the ratio of net income (proceeds) from the sale of products (goods, works, services) and the average annual value of the company's assets, while reflecting the level of efficiency of their use. The use of this indicator in the course of diagnosing the development of crisis phenomena at the enterprise is due to the fact that it makes it possible to assess the intensity of the use of resources belonging to the enterprise involved in its activities. The higher the value of the turnover ratio, the more income each monetary unit of asset value generates and vice versa;

5) to assess the ability of an enterprise to cover its debts at the expense of income from the main activity the ratio of coverage of borrowed capital at the expense of profit before interest and taxes. It is calculated as the ratio of financial results from operating activities of the enterprise and the total value of long-term and current liabilities:

6) to assess the level of liquidity of the enterprise the coverage ratio (current liquidity), which allows you to assess the degree of solvency of the enterprise due to the liquidity of its assets. Thus, the use of the two previous coefficients at the same time will make it possible to comprehensively assess the level of the company's solvency as a whole. Assessment of the company's solvency, regardless of the selected sources of repayment of obligations, is of paramount importance for identifying signs of a crisis at the enterprise, since solvency is one of the parameters by which creditors have the right to go to court with a claim to initiate a bankruptcy case of the debtor.

Let us diagnose crisis phenomena in the activities of Ukrainian enterprises on the basis of the proposed system of indicators. For the study, it is proposed to use data from open financial statements of enterprises in Kharkiv region, representing various industries, namely:

JSC "Trest Zhilstroy-1" [8], the main activity is construction;

JSC "Kharkovoblenergo" [9], works in the electric power industry;

JSC "Turboatom" [10], represents the machine building industry;

PrJSC "Confectionery factory "Kharkivchanka" [11], field of activity - food production;

PrJSC “Zavod ZhBK-13” [12], types of economic activities - lease and operation of real estate, manufacture of concrete products for construction.

The results of calculating analytical indicators for Trest Zhilstroy-1 JSC for the period 2016-2020 are presented in table. 1.

Analysis presented in table. 1 data allows us to draw the following conclusions. In the structure of the enterprise's capital throughout the analyzed period, borrowed funds predominate, but their share decreases over time. At the same time, the share of equity capital, and, consequently, the level of financial independence of Trest Zhilstroy-1 JSC, is increasing, which is a positive trend. The share of net working capital in the structure of assets is quite high, has a positive trend and by 2020 is $50 \%$. 
Table 1

Dynamics of indicators for assessing the crisis phenomena of Trest Zhilstroy-1 JSC in 2016-2020

\begin{tabular}{|l|c|c|c|c|c|c|c|}
\hline \multicolumn{1}{|c|}{ Index } & $\begin{array}{c}\text { Recommended } \\
\text { value, } \\
\text { dynamics }\end{array}$ & $2016 \mathrm{y}$. & $2017 \mathrm{y.}$ & $2018 \mathrm{y}$. & $2019 \mathrm{y}$. & $2020 \mathrm{y}$. \\
\hline Financial independence ratio (FIR) & $\geq 0,5$ & 0,020 & 0,297 & 0,237 & 0,420 & & 0,367 \\
\hline Share of PSCs in asset value (SPSC) & $>0$, growth & 0,381 & 0,399 & 0,473 & 0,618 & & 0,500 \\
\hline Return on assets ratio (RAR) & $>0$, growth & 0,008 & 0,009 & 0,012 & 0,006 & & 0,001 \\
\hline Operating profitability ratio (OPR) & $>0$, growth & 0,072 & 0,044 & 0,037 & 0,026 & & 0,014 \\
\hline Asset turnover ratio (ATR) & growth & 0,300 & 0,339 & 0,550 & 0,443 & & 0,310 \\
\hline $\begin{array}{l}\text { Ratio of debt capital coverage at the } \\
\text { expense of earnings before interest } \\
\text { and taxes (RDCC) }\end{array}$ & growth & 0,022 & 0,022 & 0,026 & 0,021 & & 0,007 \\
\hline Current liquidity ratio (CLR) & $1,5-2$ & 1,710 & 1,736 & 1,995 & 2,826 & & 2,118 \\
\hline
\end{tabular}

The return on assets ratio, increasing by 2018 , decreases significantly in 2020 and takes a minimum value of 0.001 . Therefore, for $1 \mathrm{UAH}$ of the value of assets, the enterprise generates UAH 0.001 of net profit. Such dynamics is negative, indicating a drop in the efficiency of using total assets. The dynamics of the operating profitability ratio is negative throughout the entire study period, the value of the indicator is reduced by more than 5 times (from 0.072 in 2016 to 0.014 in 2020), which indicates a significant decrease in the level of efficiency of the main activity of the enterprise. Thus, we can conclude that there are symptoms of the development of crisis phenomena in the field of the profitability of the enterprise and the formation of its financial results.

Asset turnover ratio has an upward trend in 20162018, but in 2019-2020 declines, returning to the level of 2016. This situation suggests that the enterprise has the potential to increase the rate of resource turnover, but at the moment it is not being used.
Debt capital coverage ratio due to operating profit in 2016-2019 is approximately at the same level, but in 2020 it is sharply reduced by three times. The value of the indicator suggests that in 2020, at the expense of profit before interest and taxes, a company can cover only $7 \%$ of all its liabilities. At the same time, the dynamics of the current liquidity ratio is positive, therefore, the level of solvency of Trest Zhilstroy-1 JSC is maintained due to the sufficiency of current assets.

Thus, we can conclude that signs of the development of crisis phenomena in the activities of Trest Zhilstroy-1 JSC are observed exclusively in the field of profitability and the formation of financial results. At the enterprise, the efficiency of the main activity decreases, the level of return on the assets used decreases and the ability to pay off its liabilities due to financial results decreases.

Let's calculate the set of indicators for JSC "Kharkovoblenergo" (table 2).

Table 2

Dynamics of indicators for assessing the crisis phenomena of Kharkovoblenergo JSC in 2016-2020

\begin{tabular}{|l|c|c|c|c|c|c|}
\hline \multicolumn{1}{|c|}{ Index } & $\begin{array}{c}\text { Recommended } \\
\text { value, } \\
\text { dynamics }\end{array}$ & $2016 \mathrm{y}$. & $2017 \mathrm{y}$. & $2018 \mathrm{y}$. & $2019 \mathrm{y}$. & $2020 \mathrm{y}$. \\
\hline Financial independence ratio (FIR) & $\geq 0,5$ & 0,671 & 0,695 & 0,640 & 0,740 & 0,660 \\
\hline Share of PSCs in the value of assets (SPSC) & $>0$, growth & 0,135 & 0,114 & 0,144 & 0,181 & 0,146 \\
\hline Return on assets ratio (RAR) & $>0$ growth & $-0,027$ & 0,006 & 0,000 & 0,000 & 0,001 \\
\hline Operating profitability ratio (OPR) & $>0$ growth & $-0,017$ & 0,002 & $-0,002$ & $-0,058$ & $-0,001$ \\
\hline Asset turnover ratio (ATR) & growth & 1,820 & 1,427 & 1,512 & 0,477 & 0,593 \\
\hline $\begin{array}{l}\text { Ratio of debt capital coverage at the expense } \\
\text { of earnings before interest and taxes (RDCC) }\end{array}$ & growth & $-0,096$ & 0,010 & $-0,009$ & $-0,122$ & $-0,002$ \\
\hline Current liquidity ratio (CLR) & $1,5-2$ & 1,463 & 1,467 & 1,470 & 2,052 & 1,526 \\
\hline
\end{tabular}

The analysis of the conducted calculations made allows us to establish the following. The level of financial stability in the structure of the company's capital is quite high, as evidenced by the excess of the coefficient of financial independence of the recommended value of 0.5 throughout the study period. The share of net working capital is quite stable, it is about $15 \%(+-3 \%)$ in the total assets.

The return on assets ratio in 2016 was negative, i.e. the company experienced a net loss. In 2017-2020 the 
indicator has a value above 0 , but very low - for $1 \mathrm{UAH}$ of asset value, the enterprise generates UAH 0.001 of net profit. The operating profitability ratio for almost the entire period (except for 2017) has a negative value, i.e. the main activity of the enterprise is unprofitable. Thus, as in the case of the previous enterprise, signs of the presence of crisis phenomena in the formation of financial results and performance efficiency were revealed.

Note that in 2019-2020. there is a sharp decrease (3 times) in the asset turnover ratio, which also indicates a decrease in the efficiency of their use.

The negative financial results of the company's operating activities lead to the fact that JSC "Kharkivoblenergo" does not have the ability to repay its obligations at the expense of financial results.
Therefore, the current solvency is supported by a sufficient volume of current assets, which is confirmed by the high value of the current liquidity ratio and its compliance with the recommended interval.

Thus, we can conclude that JSC "Kharkovoblenergo", like JSC "Trust Zhilstroy-1" is characterized by the presence of crisis phenomena in the field of profitability. The situation is aggravated by the presence of losses from core activities, which may lead to a further deterioration of the financial condition and the spread of crisis phenomena to other areas of the enterprise.

The dynamics of analytical indicators, the calculation of which was carried out for the machinebuilding enterprise JSC "Turboatom", is presented in table 3 .

Table 3

Dynamics of indicators for assessing the crisis phenomena of Turboatom JSC in 2016-2020

\begin{tabular}{|l|c|c|c|c|c|c|}
\hline \multicolumn{1}{|c|}{ Index } & $\begin{array}{c}\text { Recommended } \\
\text { value, } \\
\text { dynamics }\end{array}$ & $2016 \mathrm{y.}$ & $2017 \mathrm{y.}$ & $2018 \mathrm{y}$. & $2019 \mathrm{y.}$ & $2020 \mathrm{y}$. \\
\hline Financial independence ratio (FIR) & $\geq 0,5$ & 0,712 & 0,743 & 0,739 & 0,723 & 0,730 \\
\hline Share of PSCs in the value of assets (SPSC) & $>0$, growth & 0,377 & 0,193 & 0,242 & 0,313 & 0,349 \\
\hline Return on assets ratio (RAR) & $>0$, growth & 0,225 & 0,098 & 0,101 & 0,042 & 0,030 \\
\hline Operating profitability ratio (OPR) & $>0$, growth & 1,022 & 0,621 & 0,605 & 0,257 & 0,067 \\
\hline Asset turnover ratio (ATR) & growth & 0,457 & 0,329 & 0,346 & 0,380 & 0,194 \\
\hline $\begin{array}{l}\text { Ratio of debt capital coverage at the expense } \\
\text { of earnings before interest and taxes (RDCC) }\end{array}$ & growth & 0,864 & 0,481 & 0,469 & 0,260 & 0,040 \\
\hline Current liquidity ratio (CLR) & $1,5-2$ & 2,348 & 1,901 & 2,064 & 2,251 & 2,424 \\
\hline
\end{tabular}

Analysis of the dynamics calculated in table 3 indicators allows us to draw such conclusions.

The company has a predominant share of equity capital in the structure of assets (over 70\%), which provides it with a high level of financial independence in the capital structure. The share of PSCs, despite a slight decrease in 2017-2018, is quite high and by 2020 will return to the level of the beginning of the period (35\% in the structure of assets).

However, negative trends are observed in the dynamics of profitability ratios, as in previous business entities. Thus, the return on assets by 2020 falls to 0.03 (which is 8 times less than in 2016). Operating profitability is also declining, but at a slower pace (halving by the end of the analyzed period). Similarly, negative dynamics is observed in the asset turnover ratio (more than a 2-fold reduction). All this testifies to a sharp decrease in the efficiency of JSC "Turboatom" and, accordingly, the development of crisis phenomena in the field of profitability and turnover of its assets.

The negative dynamics of financial results led to a decrease in the debt coverage ratio due to operating profit. At the same time, the enterprise as a whole is solvent, the value of the current liquidity ratio in the analyzed period is quite high.

Consequently, the crisis phenomena in the activities of Turboatom JSC affect the areas of profitability and turnover of its assets.

Let's calculate the complex of financial ratios for PrJSC "Confectionery factory "Kharkivchanka" (table 4).

Analysis of the results obtained indicates the following. Thus, the share of the company's equity capital is on average $40 \%$ of the total sources of funds. At the same time, the value of the coefficient of financial independence, although it does not reach the recommended level, is stable, which suggests that there are no crisis phenomena in the capital structure of PrJSC "Confectionery factory "Kharkivchanka". However, there is a negative value of net working capital, which indicates an insufficient level of financial independence and problems in the structure of the company's assets. 
Table 4

Dynamics of indicators for assessing the crisis phenomena of PrJSC "Confectionery factory "Kharkivchanka" in 2016-2020

\begin{tabular}{|l|c|c|c|c|c|c|}
\hline \multicolumn{1}{|c|}{ Index } & $\begin{array}{c}\text { Рекоменд. } \\
\text { значение, } \\
\text { динамика }\end{array}$ & 2016 у. & 2017 у. & 2018 у. & 2019 у. & 2020 у. \\
\hline Financial independence ratio (FIR) & $\geq 0,5$ & 0,395 & 0,440 & 0,418 & 0,370 & 0,389 \\
\hline Share of PSCs in the value of assets (SPSC) & $>0$,growth & $-0,269$ & $-0,451$ & $-0,462$ & $-0,483$ & $-0,557$ \\
\hline Return on assets ratio (RAR) & $>0$,growth & 0,020 & 0,079 & $-0,003$ & $-0,016$ & $-0,003$ \\
\hline Operating profitability ratio (OPR) & $>0$,growth & 0,050 & 0,134 & 0,010 & $-0,010$ & 0,008 \\
\hline Asset turnover ratio (ATR) & growth & 0,712 & 0,872 & 0,875 & 0,789 & 0,699 \\
\hline $\begin{array}{l}\text { Ratio of debt capital coverage at the expense } \\
\text { of earnings before interest and taxes (RDCC) }\end{array}$ & growth & 0,052 & 0,192 & 0,015 & $-0,011$ & 0,009 \\
\hline Current liquidity ratio (CLR) & $1,5-2$ & 0,210 & 0,192 & 0,206 & 0,233 & 0,089 \\
\hline
\end{tabular}

The return on assets ratio becomes negative in 2018-2020, which is explained by the presence of losses at the enterprise. At the same time, the company's operating activities were unprofitable only in 2019. This indicates that the occurrence of net losses is due to an increase in costs for other types of activities (financial, investment). In 2020, profitability indicators slightly improved compared to 2019 and returned to the level of 2018, but in general, the efficiency of the study enterprise is extremely low.

The dynamics of the asset turnover ratio is characterized by insignificant fluctuations and a decrease by 2020 .
The coefficients characterizing the ability of the enterprise to fulfill its obligations have very low values and negative dynamics. In particular, current assets cover on average about $20 \%$ of current liabilities, and operating profit - about $1 \%$ (2020).

Thus, we can conclude that the crisis phenomena in the activities of PrJSC "Confectionery factory "Kharkivchanka" affect the sphere of profitability, the structure of assets and this negatively affects the ability of the enterprise to fulfill its obligations.

The dynamics of analytical indicators, the calculation of which was carried out for PJSC "Zavod ZhBK-13", is presented in table 5 .

Table 5

Dynamics of indicators for assessing the crisis phenomena of PJSC "Zavod ZhBK-13" in 2016-2020

\begin{tabular}{|l|c|c|c|c|c|c|}
\hline \multicolumn{1}{|c|}{ Index } & $\begin{array}{c}\text { Recommended } \\
\text { value, } \\
\text { dynamics }\end{array}$ & $2016 \mathrm{y}$. & $2017 \mathrm{y}$. & $2018 \mathrm{y}$. & $2019 \mathrm{y}$. & $2020 \mathrm{y}$. \\
\hline Financial independence ratio (FIR) & $\geq 0,5$ & 0,739 & 0,753 & 0,301 & 0,191 & 0,142 \\
\hline Share of PSCs in the value of assets (SPSC) & $>0$, growth & 0,143 & 0,269 & 0,072 & $-0,756$ & $-0,830$ \\
\hline Return on assets ratio (RAR) & $>0$ growth & 0,151 & 0,136 & 0,040 & 0,042 & $-0,060$ \\
\hline Operating profitability ratio (OPR) & $>0$ growth & 0,112 & 0,074 & 0,051 & 0,120 & 0,031 \\
\hline Asset turnover ratio (ATR) & growth & 1,186 & 1,928 & 1,454 & 0,781 & 0,332 \\
\hline $\begin{array}{l}\text { Ratio of debt capital coverage at the expense } \\
\text { of earnings before interest and taxes (RDCC) }\end{array}$ & growth & 0,737 & 0,672 & 0,109 & 0,132 & 0,010 \\
\hline Current liquidity ratio (CLR) & $1,5-2$ & 1,611 & 2,130 & 1,106 & 0,065 & 0,032 \\
\hline
\end{tabular}

Let's analyze the data presented in the table. Thus, the dynamics of the financial independence ratio is extremely negative, the indicator decreased in the analyzed period by more than 5 times, the share of own funds decreased from $74 \%$ to $14.2 \%$. This indicates a sharp increase in the dependence of the enterprise on borrowed sources of financing. At the same time, the PSC indicator in 2019-2020 acquired a negative value, which confirms the conclusion about the violation of financial stability.

The return on assets ratio in the analyzed period was decreasing and in 2020 it also reached a negative value, the company entered the unprofitable zone. At the same time, operating activities are profitable, but the value of the operating profitability ratio also significantly decreases during the analyzed period. The asset turnover ratio has a similar downward trend.

Note that in 2019-2020 there was a sharp decline in indicators reflecting the company's ability to fulfill its obligations - for example, due to operating profit, the enterprise is able to cover $1 \%$ of its liabilities, and due to current assets $-3.2 \%$. Therefore, we see rapid development deep crisis at the enterprise, which affects almost all aspects of its financial condition. 
The generalized results of the analysis and enterprises are presented in table 6 . diagnostics of crisis phenomena in the activities of

Table 6

Results of diagnostics of crisis phenomena in the activities of enterprises

\begin{tabular}{|c|c|c|}
\hline Company & Main activity (industry) & $\begin{array}{c}\text { Identified areas of development of crisis } \\
\text { phenomena }\end{array}$ \\
\hline JSC "Trust Zhilstroy-1" & building & profitability \\
\hline JSC "Kharkovoblenergo" & power transmission & profitability, asset turnover \\
\hline JSC "Turboatom" & Machine building & profitability, asset turnover \\
\hline $\begin{array}{c}\text { PrJSC "Confectionery } \\
\text { factory" Kharkivchanka " }\end{array}$ & food production & $\begin{array}{c}\text { folvency } \\
\text { financial stability profitability, resource turnover, }\end{array}$ \\
\hline PrJSC Zavod ZhBK-13 & $\begin{array}{c}\text { leasing and operating real } \\
\text { estate }\end{array}$ & \\
\hline
\end{tabular}

Thus, the analysis made it possible, using the formed system of financial indicators, to identify in the activities of the selected enterprises the spheres in which the emergence and development of crisis phenomena is observed and which, therefore, need the priority application of anti-crisis management influences.

\section{Conclusions and prospects for further research}

Thus, the formed set of financial indicators can be used in a complex to assess the presence and depth of crisis phenomena, highlight the key areas of their occurrence and development in the activities of enterprises of various industries and activities.

Timely identification and identification of the signs of a crisis at the enterprise creates the prerequisites for an adequate choice and effective application of mechanisms to prevent further development or neutralize negative consequences. In this regard, further research is supposed to be directed at the formation of complexes of anti-crisis measures, depending on the identified areas of development of the crisis and the development of criteria for assessing their effectiveness and appropriateness.

\section{References}

1. State Statistics Service of Ukraine. URL: www.ukrstat.gov.ua [in Ukrainian]

2. Tereshchenko, O.O. (2006). Anti-crisis financial management at the enterprise. KNEU, Kyiv. [in Ukrainian]

3. Matvijchuk, A.V. (2010). Modeling of financial stability of enterprises using the theory of fuzzy logic, neural networks and discriminant analysis. Visnyk of the National Academy of Sciences of Ukraine, 9, 24-46. [in Ukrainian]

4. On approval of the Regulations on determining the amount of credit risk by banks of Ukraine for active banking operations. (2016). Document v0351500-16, valid, current version - Revision on August 17, 2021, on the basis v0087500-21.

URL: https://zakon.rada.gov.ua/laws/show/\%20v0351500-16\#Text [in Ukrainian]

5. Blank, I.A (2006). Anti-crisis financial management of the enterprise. El'ga, Nika-Centr, Kyiv. [in Russian]

6. Berest, M., Koiuda, O., Sobolieva, H. (2020). Formation of indicators system for diagnosing the development of crisis phenomena in the activities of an enterprise. Municipal economy of cities, 7(160), 11-17. DOI: https://doi.org/10.33042/2522-1809-2020-7-160-11-17

7. Zhytlobud-1. URL: https://gs1.com.ua

8. Aktsionerne tovarystvo "Kharkivoblenerho". URL: https://www.oblenergo.kharkov.ua

9. Ukrainian Energy Machines. URL: https://ukrenergymachines.com/en

10. Confectionery factory «Kharkovchanka». URL: https://biscuit.com.ua/factory kharkov

11. PrAT "Zavod ZBK-13". URL: http://zbk.nr-avers.com.ua

Reviewer: Doctor of Economic Sciences, Professor A.E. Achkasov, O.M. Beketov National University of Urban Economy in Kharkiv, Ukraine.

Author: BEREST Maryna Mykolaivna

Candidate of Economic Sciences (PhD), Associate Professor, Associate Professor of the Department

Simon Kuznets Kharkiv National University of Economics

E-mail-maryna.berest@hneu.net

ID ORCID: https://orcid.org/0000-0002-2410-3210

Author: KOIUDA Oleksandr Pavlovych

Candidate of Economic Sciences (PhD), Associate Professor, Associate Professor of the Department

O.M. Beketov National University of Urban Economy in Kharkiv

E-mail-ak1261698@gmail.com

ID ORCID: https://orcid.org/0000-0002-4205-8900 


\title{
АНАЛІЗ ТА ДІАГНОСТИКА КРИЗОВИХ ЯВИЩ В ДІЯЛЬНОСТІ УКРАЇНСЬКИХ ПІДПРИЕМСТВ
}

\author{
М.М. Берест ${ }^{1}$, О.П. Коюда ${ }^{2}$
}

${ }^{1}$ Харківський національний економічний університет імені Семена Кузнеця, Україна

${ }^{2}$ Харківський національний університет міського господарства імені О.М. Бекетова, Україна

Запропоновано ключові аналітичні напрямки $і$ розкрито економічний зміст фінансових показників діагностики кризових явищ в діяльності суб'єктів господарювання. Розкрито особливості оцінки фінансового стану підприємства та розглянуті відповідні фінансові показники для діагностики кризових явищ в діяльності підприємств України.

Визначено, щзо діагностика кризового стану підприємства повинна бути комплексної та базуватися на використанні фінансових показників за різними аналітичними напрямами. Розроблено комплекс фінансових показників для проведено аналіз розвитку кризових явищ в діяльності підприємств: коефіцієнт фінансової незалежності (автономіі) для очінки структури капіталу; співвідношення обігового капіталу та загальної вартості активів для оцінки структури активів; коефіцієнт рентабельності активів для оцінки прибутковості; коефіцієнт оборотності активі для оцінки швидкості обороту ресурсів підприємства; коефіцієнт покриття позикового капіталу для оиінки здатності підприємства погасити свої борги; коефіиієнт покриття для оичінки рівня ліквідності підпиємства.

На підставі розробленого комплексу показників була проведена оџінка кризових явищ на підприємствах машинобудування, будівництва та виробництва продуктів харчування, а саме: $A T$ «рест Житлобуд-1», АT «Харківобленерго», АТ «Турбоатом» та ПрАТ «Кондитерська фабрика «Харків'янка» за період 2016$2020 \mathrm{pp}$.

Проведений аналіз дозволив, за допомогою використання сформованої системи фінансових показників, виявити в діяльності обраних підприємств сфери, в яких спостерігається виникнення і розвиток кризових явищ і які, отюе, потребують першочергового застосуванні антикризових управлінських впливів.

Ключові слова: аналіз, діагностика кризових явищ, фінансові показники, прибутковість, фінансова стійкість. 